\title{
Length-weight relationships and condition factor of eight fish species inhabiting the Rocha Lagoon, Uruguay
}

\author{
Cesar Rodriguez ${ }^{1}$, Oscar Galli², Daniela Olsson ${ }^{1}$, Javier S. Tellechea ${ }^{1}$, Walter Norbis $^{1 *}$
}

\author{
${ }^{1}$ Laboratorio de Fisiologia de la Reproducción y Ecología de Peces. Departamento de Biología Animal. Instituto de Biología. Facultad \\ de Ciencias, UdelaR \\ (Igua 4225, CP 11400, Montevideo Uruguay) \\ ${ }^{2}$ Unidad de Relaciones y Cooperación Sector Productivo. Servicio Central de Extensión y Actividades en el Medio (SCEAM). UdelaR \\ (Brandzen 1956 apto 201 CP 11200 Montevideo Uruguay) \\ *Corresponding author: wnorbis@fcien.edu.uy
}

Length-weight relationships are commonly used in fisheries biology to convert length measures into weight and to ascertain the growth characteristics related to those variables. On the other hand, length-weight relationships are used for estimating fishes' condition factor, and these values are used for comparing the "condition", "fatness" or "well-being" of fish (LE CREN, 1951; FROESE, 2006). The condition factor could reflect the physiological state of a fish, which is influenced by both intrinsic (gonadal development, organic reserves, presence or absence of food in the gut) and extrinsic (food availability, environmental variability) factors (NIKOLSKY, 1969). The coastal lagoons on the south-eastern Uruguayan Atlantic coast (José Ignacio, Garzón, Rocha, Castillo, and Negra) serve as feeding (NORBIS; GALLI, 2004; OLSSON et al., 2013), reproduction (VIZZIANO et al., 2002), nursery grounds (SANTANA; FABIANO, 1999) and growing areas (BORTHAGARAY et al., 2011) for several marine and estuarine fishes which sustain local artisanal fisheries (SANTANA; FABIANO, 1999; SAONA et al., 2003; FABIANO; SANTANA, 2006). The Rocha Lagoon is a shallow, brackish, microtidal lagoon ( $a r e a=72$ $\mathrm{km}^{2}$, mean depth $0.58 \mathrm{~cm}$, tide amplitude $<40 \mathrm{~cm}$ ) on the southwestern coast of the Atlantic Ocean ( $34^{\circ} 33^{\prime} \mathrm{S}$, $54^{\circ} 22^{\prime} \mathrm{W}$ ), being part of a MaB / UNESCO Biosphere Reserve. The lagoon is separated from the sea by a sandbar parallel to the coast that opens naturally several times in the course of the year as a consequence of the action of southern storms and/or freshwater discharges due to rain or human action (CONDE et al., 2000). The intermittently open-closed bar creates a marked salinity gradient as a consequence of marine intrusion (CONDE et al., 2000). The Rocha Lagoon is highly productive and land-use changes that have occurred in the basin, as well as ongoing Submitted on: 10/06/2015 eutrophication and the artificial modification of the frequency of connection with the ocean, may have had a synergistic effect on its ecological functioning (BONILLA et al., 2006). Fish length and weight data are scarce for Uruguayan coastal lagoons and there are no estimates of the condition factor for fishes in these ecosystems. The aim of the present study was to estimate the length-weight relationships of eight fish species of the Rocha Lagoon, caught by artisanal fisheries using different kinds of gear according to the target species, and assess the relative weight (Wr) as a condition factor for each species.

Monthly sampling was carried out in the Rocha Lagoon - Uruguay (34 $\left.33^{\prime} \mathrm{S}, 54^{\circ} 22^{\prime} \mathrm{W}\right)$, between November 2009 and February 2012. Fishes were caught by five multi-species fisheries that operate in different parts of the lagoon. The silverside fishery (Odontesthes argentinensis) used a beach seine ( $40 \mathrm{~mm}$ mesh in the wings and 10 or $20 \mathrm{~mm}$ at the cod ends, vertical opening 1 $\mathrm{m}$, and of $200 \mathrm{~m}$ or $400 \mathrm{~m}$ length) and was directed from the coast using a boat. The mullet fishery (Mugil liza) was conducted from the boat, encircling the school of fish with gillnets. In the menhaden (Brevoortia aurea) and flatfish (Paralichthys orbignyanus) fisheries set gillnets were used and moved by fishermen every 12 or 24 hours (SAONA et al., 2003). The black drum (Pogonias cromis) was a bycatch species of the flatfish fishery. The whitemouth croaker (Micropogonias furnieri) was a bycatch species of all the above-mentioned fisheries (SAONA et al., 2003) and Oligosarcus jenynsii and Lycengraulis grossidens were bycatch species of the silverside fishery. Except for $B$. aurea (this species was the subject of monthly sampling to study its reproductive cycle), the remaining species were sampled opportunistically, and the pooled data of all the species were analyzed in order to minimize the effect of season, sex, age and maturity stage. The total 
length $(\mathrm{mm})\left(\mathrm{L}_{\mathrm{T}}\right)$ and total body weight $(\mathrm{g})\left(\mathrm{W}_{\mathrm{T}}\right)$ of all the individuals of each species were recorded.

The parameters for the equation $\mathrm{W}_{\mathrm{T}}=\mathrm{a} \mathrm{L}_{\mathrm{T}}{ }^{\mathrm{b}}$ (RICKER, 1973) were estimated by linear regression, after a logarithmic transformation of the variables. Extreme outliers were removed before fitting the linear regression. The statistical significance of the slope (b), the intercept (a) and the correlation coefficient (r) using Student's $t$-test (SOKAL; ROHLF, 1995) were analyzed. In order to check whether fish growth was statistically different from isometric growth $\left(\mathrm{H}_{0}: \mathrm{b}=3\right)$, a Student $t$-test was performed. The relative weight as condition factor $(\mathrm{Wr})$ was calculated for each fish species by the following expression: $\mathrm{Wr}=\mathrm{W}_{\mathrm{T}} / \mathrm{a}_{\mathrm{m}} \mathrm{L}_{\mathrm{T}}^{\text {bm }}$, (FROESE, 2006). The median $\mathrm{Wr}$ with lower and upper percentiles $25 \%$ and $75 \%$ respectively, were calculated for each species and the values compared applying the Kruskall - Wallis test non - parametric analysis of variance (SOKAL; ROHLF, 1995). In all the tests, the significance level considered was $p=0.05$.

A total of 2067 specimens belonging to eight fish species (Table 1) representing seven families (Engraulidae, Clupeidae, Characidae, Mugilidae, Atherinopsidae, Sciaenidae and Paralichthyidae) were used for calculation of the $\mathrm{L}_{\mathrm{T}}-\mathrm{W}_{\mathrm{T}}$ relationships (Table 1). All the estimated regression coefficients were highly significant $(p<0.0001)$, and ranged from 2.82 for $O$. argentinensis to 3.34 for $B$. aurea. All the $\mathrm{b}$ values were within the expected range from 2.5 to 3.5 (FROESE, 2006). In all cases more than the $84 \%$ of $\mathrm{W}_{\mathrm{T}}$ variability was explained by the models (Table 1). The species M. furnieri, $O$. argentinensis and M. liza grew more quickly in length than in weight (i.e. negative allometry $\mathrm{b}<3$ ), while B.aurea, $P$. cromis and $P$. orbignyanus grew more rapidly in weight than in length (positive allometry $\mathrm{b}>3$ ). For $O$. jenynsii and L. grossidens the growth was isometric $(b=3)$ (Table 1$)$.

Species such as L. grossidens (FROESE; PAULY, 2015), M. furnieri (VAZZOLER; IWAI, 1971; YAMAGUTI et al., 1973; MAGRO et al., 2000; NORBIS; VEROCAI, 2002; RODRIGUEZ DA COSTA; ARAÚJO, 2003; CAROZZA et al., 2004; CARNEIRO et al., 2005; JOYEUX et al., 2009; BORTHAGARAY et al., 2011; PASSOS et al., 2012; SEGURA et al., 2012; GURDEK; ACUÑA PLAVAN, 2014; FROESE; PAULY, 2015; GALLI; NORBIS, 2016), O. jenynsii (ANTONETTI et al., 2014), and M. liza (FROESE; PAULY, 2015) that have several published estimates of slopes, presented values within or near the confidence limits of the present study.
On the other hand, $O$. argentinensis and $P$. orbignyanus that inhabit Brazilian coastal waters had comparatively higher values (HAIMOVICI; VELAZCO, 2000) than our estimates for the Rocha Lagoon. The black drum P. cromis had higher values than the individuals which inhabit Argentinian (URTEAGA; PERROTA, 2001) and Brazilian coastal waters (HAIMOVICI; VELAZCO, 2000). Comparing regression coefficient estimates of the present study with published values for $\log \mathrm{a}$ vs $\mathrm{b}$ plot (FROESE, 2006), most of the values fell within the ellipse, except for P. cromis. However, the estimated parameters of length-weight relationships given in this study should be used with caution as the length ranges of the specimens available were determined by the selectivity of the fishing gear used by the artisanal fisheries that operated in the Rocha coastal lagoon (SAONA et al., 2003). Thus, the use of length-weight relationships to estimate the weight for a given length and convert length observations into weights should be done only for specimens of lengths within the length ranges used in the estimate parameters.

The highest median values of $\mathrm{Wr}(>1)$ were recorded for $M$. furnieri, followed by $O$. argentinensis and. $P$. orbignyanus. The lowest values of $\mathrm{Wr}(<1)$ were recorded for L. grossidens, followed by M. liza, B. aurea, O. jenynsii and P. cromis (Table 1). The condition factor is influenced by the reproduction and feeding of individuals and during the sampling period (November 2009 to February 2012), springs and summers were more numerous than autumns and winters. However, non-significant differences were found between species for $\mathrm{Wr}$ (Kruskall - Wallis test $=2.239, p=0.945>0.05$ ), and a high overlap was found between lower and upper percentiles $(25 \%$ and $75 \%$, respectively) for values of $\mathrm{Wr}$ calculated by species (Table 1). This suggests that most individuals of each of the species in the Rocha Lagoon would be found in a similar condition. This is the first study that has estimated the condition factors and length-weight regression coefficients for eight species caught by artisanal fishery in a Uruguayan coastal lagoon. Estimates of length-weight relationships are used for between habitat comparisons of the growth of a specific species as they are considered to provide an index of habitat trophic state (TSOUMANI et al., 2006). The relative weight (Wr) as a condition factor is recommended for use across populations or species (FROESE, 2006) and can provide information on the general condition of fishes in the habitat in which they live and alterations in population density. Thus, the estimated $\mathrm{Wr}$ for each species can provide a useful tool 
Table 1. Estimated parameters of length-weight relationships and condition factor for fishes collected from Rocha Lagoon - Uruguay $(\mathrm{Max}=$ maximum length $(\mathrm{cm})$; Min=minimum length $(\mathrm{cm})$; $\mathrm{n}=$ number of individuals included in the analysis; $\mathrm{a}=$ intercept; $\mathrm{b}=$ slope; $\mathrm{CI} 95 \%=$ confidence interval; $(0)$ : Isometry; $(+)=$ significant positive allometry; $(-)$ :significant negative allometry); $r=$ correlation coefficient; $\mathrm{r}^{2}=$ coefficient of determination; $\mathrm{Wr}=$ Relative weight).

\begin{tabular}{lccccccccc}
\hline \multirow{2}{*}{ Fish species } & \multicolumn{2}{c}{ Total length } & \multicolumn{4}{c}{ Parameters length - weight relationships } & \multicolumn{2}{c}{ Median } & \multicolumn{2}{c}{ Percentil } \\
& Min & Max & $\mathrm{n}$ & $\mathrm{a}$ & $\mathrm{b} \pm \mathrm{CI} 95 \%$ & $\mathrm{r}$ & $\mathrm{r}^{2}$ & $\mathrm{Wr}$ & $25 \%-75 \%$ \\
\hline Lycengraulis grossidens & 15.5 & 22.4 & 220 & 0.008 & $3.09 \pm 0.20(0)$ & 0.93 & 0.86 & 0.998 & $0.946-1.061$ \\
Brevoortia aurea & 8.7 & 32.1 & 382 & 0.006 & $3.34 \pm 0.02(+)$ & 0.98 & 0.97 & 0.995 & $0.947-1.052$ \\
Oligosarcus jenynsii & 12.5 & 22.1 & 92 & 0.011 & $3.10 \pm 0.30(0)$ & 0.92 & 0.85 & 0.987 & $0.915-1.088$ \\
Mugil Liza & 4.7 & 37.7 & 254 & 0.019 & $2.87 \pm 0.03(-)$ & 0.99 & 0.99 & 0.997 & $0.959-1.041$ \\
Odontesthes argentinensis & 11.7 & 26.0 & 602 & 0.015 & $2.82 \pm 0.09(-)$ & 0.95 & 0.90 & 1.003 & $0.945-1.061$ \\
Micropogonias furnieri & 18.0 & 46.0 & 258 & 0.015 & $2.87 \pm 0.10(-)$ & 0.97 & 0.94 & 1.011 & $0.929-1.072$ \\
Pogonias cromis & 33.0 & 66.5 & 46 & 0.003 & $3.31 \pm 0.30(+)$ & 0.97 & 0.94 & 0.986 & $0.928-1.063$ \\
Paralichthys orbignyanus & 5.2 & 62.5 & 213 & 0.008 & $3.09 \pm 0,03(+)$ & 0.99 & 0.98 & 1.002 & $0.940-1.065$ \\
\hline
\end{tabular}

and constitute an important baseline for future studies for the comparison and examination of overall growth or as an indicator of habitat quality.

\section{ACKNOWLEDGEMENTS}

This research was supported by PEDECIBA BIOLOGIA (Program Development of Basic Sciences, Uruguay) and the data were collected during the sampling surveys related to the Master's Thesis in Zoology of CR development (Project: "Reproductive cycle and the effect of the population structure and environmental conditions in the reproductive potential of the Brazilian menhaden (Brevoortia aurea) in Rocha Lagoon"). The authors would especially like to thank the fishermen Santiago, Jorge and Luis Ballesteros and Roberto Clemente (Tito) for their assistance in the field surveys.

\section{REFERENCES}

ANTONETTI, D. A.; LEAL, M. E.; SCHULZ, U. H. Length-weight relationships for 19 fish species from the Jacu Delta, RS, Brazil. J. Appl. Ichthyol., v. 30, n. 1, p. 259-260, 2014.

BONILLA, S.; CONDE, D.; AUBRIOT, L.; RODRÍGUEZ-GALLEGO, L.; PICCINI, C.; MEEROFF, E.; RODRÍGUEZ-GRAÑA, L.; CALLIARI, D.; GÓMEZ, P.; MACHADO, I.; BRITOS, A. Procesos estructuradores de las comunidades biologicas en lagunas costeras de Uruguay. En: MENAFRA, R.; RODRÍGUEZ-GALLEGO, L.; SCARABINO, F.; CONDE, D. (Eds.). Bases para la Conservación y el Manejo de la Costa Uruguaya. Montevideo: Vida Silvestre Uruguay, 2006, p. 611-630.

BORTHAGARAY, A. I.; VEROCAI, J.; NORBIS, W. Age validation and growth of Micropogonias furnieri (Pisces - Sciaenidae) in a temporally open coastal lagoon (South-western Atlantic - Rocha - Uruguay) based on otolith analysis. J. Appl. Ichthyol., v. 27, n. 5, p. 1212-1217, 2011 .

CARNEIRO, M. H.; GÊNOVA DE CASTRO, P. M.; DOS SANTOS TUTTI, S. L.; CYRINO-BASTOS, G. C. Pesca da corvina no sudeste do Brasil. In: ROSSI, C. L. W.; CERGOLE, M. C.; ÁVILA-DA-SILVA, A. O.; ROSSI-WONGTSCHOWSKI, C. L. D. B. (Eds.) Análise das Principais Pescarias Comerciais da Região Sudesde-Sul do Brasil: Dinâmica Populacional das Espécies em Explotação. São Paulo: Série Documentos Revizee-Score Sul, IOUSP, 2005. p. 94-100.

CAROZZA, C. C.; LASTA, C.; RUARTE, C.; COTRINA, C.; MIANZAN, H.; ACHA, M. Corvina rubia (Micropogonias furnieri). In: SÁNCHEZ, R. P.; BEZZI, S. I. (Eds.). El Mar Argentino y sus recursos pesqueros. Tomo 4. Los peces marinos de interés pesquero. Caracterización biológica y evaluación del estado de explotación. Mar del Plata: Publicaciones Especiales INIDEP, 2004. p. 255-270.

CONDE, D.; AUBRIOT, L.; SOMMARUGA, R. Changes in UV penetration associated with marine intrusions and freshwater discharge in a shallow coastal lagoon of the Southern Atlantic Ocean. Mar. Ecol. Prog. Ser., v. 207, p. 19-31, 2000.

FABIANO, G.; SANTANA, O. Las pesquerías en las lagunas costeras salobres de Uruguay. In: MENAFRA, R.; RODRÍGUEZ-GALLEGO, L.; SCARABINO, F.; CONDE, D. (Eds.). Bases para la conservación y manejo de la costa uruguaya. Montevideo: Vida Silvestre, 2006, p. 557-565.

FROESE, R. Cube law, condition factor and weight-length relationships: history, meta-analysis and recommendations. $J$. Appl. Ichthyol., 22, n. 4, p. 241-253, 2006.

FROESE, R.; PAULY, D. FishBase. Available: <http://www.fishbase.org >. Accessed:12 Feb. 2015.

GALLI, O.; NORBIS, W. Length-weight relationships and condition factor of two Sciaenid species Micropogonias furnieri and Cynoscion guatucupa from the Rio de la Plata and Uruguayan ocean coast, South-western Atlantic. Rev. Biol. Mar. Oceanogr., v. 51, n. 2, p. 347-357, 2016.

GURDEK, R.; ACUÑA PLAVAN, A. Weight-length relationships of 12 fish species from the Pando tidal creek estuary (subsystem of the Río de la Plata, Uruguay). J. Appl. Ichthyol., v. 30, n. 2, p. 426-427, 2014. 
HAIMOVICI, M.; VELASCO, G. Length-weight relationship of marine fishes from southern Brazil. Naga, ICLARM Q. v. 23, n. 1, p. 19-23, 2000.

JOYEUX, J. C.; GIARRIZZO, T.; MACIEIRA, R. M.; SPACH, H. L.; VASKE JR, T. Length-weight relationships for Brazilian estuarine fishes along a latitudinal gradient. J. Appl. Ichthyol., v. 25, n. 3, p. 350-355, 2009.

LE CREN, E. D. The length-weight relationship and seasonal cycle in gonad weight and condition in Perch (Perca fluviatilis). J. Anim. Ecol., v. 20, n. 2, p. 201-219, 1951.

MAGRO, M.; CERGOLE, M. C.; ROSSI-WONGTSCHOWSKI, C. L. D. B. Avaliação do potencial sustentável de recursos vivos na Zona Econômica Exclusiva-REVIZEE - Sintese de conhecimentos dos principais recursos pesqueiros costeiros potencialmente explotáveis na costa Sudeste-Sul do Brasil: Peixes. Ministério do Meio Ambiente: MMA - Ministério do Meio Ambiente, dos Recursos Hídricos e da Amazônia Legal CIRM - Comissão Interministerial para os Recursos do Mar, 2000. 154 p.

NIKOLSKY, G. V. Theory of the Fish Population Dynamics as the Biological Background for Rational Exploitation and Management of Fisheries Resources. Oliver and Boyd: Edinburgh, $1969.322 \mathrm{p}$.

NORBIS, W.; VEROCAI, J. Analysis of the population structure of croaker captured by the artisanal fishery of Pajas Blancas. In: VIZZIANO, D.; PUIG, P.; MESONES, C.; NAGY, G. (Eds.). The Rio de la Plata. Research to manage the environment, fish resource and the fishery in the saline front. Montevideo: Ecoplata Program, 2002, p. 175-187.

NORBIS, W.; GALLI, O. Feeding habits of the flounder Paralichthys orbignyanus (Valenciennes 1839) in a shallow coastal lagoon of the southern Atlantic Ocean: Rocha, Uruguay. Cien. Mar., v. 30, p. 619-625, 2004.

OLSSON, D.; FORNI, F.; SAONA, G.; VEROCAI, J.; NORBIS, $\mathrm{W}$. Temporal feeding habits of the whitemouth croaker $\mathrm{Mi}$ cropogonias furnieri (Desmarest, 1823) in an shallow coastal lagoon (Southern Atlantic Ocean - Uruguay). Cien. Mar., v. 39, n. 3, p. 265-276, 2013.

PASSOS, A. C.; SCHWARZ JR, R.; CARTAGENA, B. F. C.; GARCIA, A. S.; SPACH, H. L. Weight-length relationship of 63 demersal fishes on the shallow coast of Paraná, Brazil. $J$. Appl. Ichthyol., v. 28, n. 5, p. 845-847, 2012.

RICKER, W. E. Linear regressions in fishery research. J. Fish. Res. Board Can., v. 30, n. 3, p. 409-434, 1973.

RODRIGUEZ DA COSTA, M.; ARAÚJO, F. G. Length-weight relationship and condition factor of Micropogonias furnieri (Desmarest) (Perciformes, Sciaenidae) in the Sepetiba Bay,
Rio de Janeiro State, Brazil. Rev. Bras. Zool., v. 20, n. 4, p. 685-690, 2003.

SANTANA, O.; FABIANO, G. Medidas y mecanismos de administración de los recursos de las lagunas costeras del litoral Atlántico del Uruguay (lagunas José Ignacio, Garzón, de Rocha y de Castillos). Montevideo: Plan de Investigación Pesquera, INAPE-PNUD URU/92/003, 1999, 169 p.

SAONA, G.; FORNI, F.; VIZZIANO, D.; NORBIS, W. Structure by size, sex and maturity stage of the whitemouth croaker (Micropogonias furnieri, Desmarest, 1823; Teleostei Sciaenidae) in the bycatch of the artisanal fishery at Rocha Lagoon, Uruguay. Cienc. Mar., v. 29, n. 3, p. 315-324, 2003.

SEGURA, A. M.; TRINCHIN, R.; RABELLINO, J.; SCARABINO, F.; TEIXEIRA-DE MELLO, F.; CARRANZA, A. Length-weight relationships of 14 coastal fish species from Punta del Diablo (Rocha, Uruguay). J. Appl. Ichthyol., v. 28, n. 5, p. 852-853, 2012.

SOKAL, R.; ROHLF, F. Biometry: the principles and practice of statistics in biological research. $3^{\text {rd }}$ ed. New York: W. H. Freeman \& Company, 1995, 887 p.

TSOUMANI, M.; LIASKO, R.; MOUTSAKI, P.; KAGALOU, I.; LEONARDOS, I. Length-weight relationships of an invasive cyprinid fish (Carassius gibelio) from 12 Greek lakes in relation to their trophic states. J. Appl. Ichthyol., v. 22, n. 4, p. 281-284, 2006.

URTEAGA, J. R.; PERROTTA, R. G. Estudio preliminary de edad, crecimiento, distribución y área de pesca de la corvina negra, Pogonias cromis, en la zona costera de la Provincia de Buenos Aires. Informe Tecnico 43. Mar del Plata: Instituto Nacional de Investigaciones Pesqueras (INIDEP), 2001, 22 p.

VAZZOLER, G.; IWAI, M. Relatório sobre prospecção e pesca exploratória na plataforma continental do Rio Grande do Sul. Contribuições do Instituto de Oceanografia Universidade de São Paulo (Séries Oceanografia Biológica). Univ. S. Paulo, v. 25, p. 41-43, 1971.

VIZZIANO, D.; FORNI, F.; SAONA, G.; NORBIS, W. Reproduction of Micropogonias funieri in a shallow temperate coastal lagoon in the southern Atlantic. J. Fish Biol., v. 61, n. sA, p. 196-206, 2002.

YAMAGUTI, N.; ZANETI, E. M.; KAWAKAMI, E. Estudo preliminar sobre o ciclo de vida dos Sciaenidae. 2. Composição da população em classes de idade aspectos do crescimento. In: Relatório sobre a segunda pesquisa oceanográfica e pesquisa do Atlántico Sul entre Torres e Maldonado $\left(29^{\circ} \mathrm{S}-35^{\circ} \mathrm{S}\right)$. Programa Rio Grande do Sul II, 1973, p. 293-306. 